\title{
PEDOPHILIA \\ (DITINJAU DARI ASPEK PELAKU, KRIMINALITAS DAN PERLINDUNGAN ANAK)
}

\author{
Ratna Azis Prasetyo \\ Universitas Airlangga, Indonesia \\ E-mail: ratna.azis.prasetyo@fisip.unair.ac.id
}

\begin{abstract}
This article aims to explain the concept of pedophilia in terms of the perpetrators, criminality and child protection aspects. During this time children who are victims of pedophiliac suffer prolonged psychological injuries and even lead to death. Meanwhile, the legal settlement is not yet comparable to the injuries suffered by the victims and light punishment tends to make the sexual violence repeated. One of the light sentences for pedophiliacs is that the criminal law in this country has not specifically regulated criminal offenses and on the other hand, the concept of pedophilia is still considered as a mental disorder. Therefore, in handling it is not enough to rely on a legal approach, more than that the handling orientation needs to be directed at child protection. This is done by taking preventive measures such as fostering social sensitivity of the community, optimizing the role of social agents such as local social and institutional organizations and instilling early sex education in children.
\end{abstract}

Keywords: pedophilia; criminality; child protection; sexual abuse

Abstrak. Artikel ini bertujuan untuk menjelaskan konsep pedophilia ditinjau dari aspek pelaku, kriminalitas dan perlindungan anak. Selama ini anak-anak yang menjadi korban para pedophiliac mengalami luka psikologis berkepanjangan dan bahkan berujung kematian. Sementara itu, penyelesaian secara hukum dirasa belum sebanding dengan luka yang dialami korban dan hukuman yang ringan cenderung membuat tindakan kekerasan seksual tersebut terulang. Hukuman yang ringan bagi para pedophiliac ini salah satunya karena hukum pidana di negara ini belum mengatur secara khusus dalam delik pidana dan disisi lain, konsep pedophilia ini masih dianggap sebagai salah satu gangguan mental. Oleh sebab itu, dalam penanganannya tidak cukup dengan mengandalkan pendekatan hukum, lebih dari itu orientasi penanganan perlu diarahkan pada perlindungan anak. Caranya dengan melakukan upaya-upaya preventif seperti menumbuhkan kepekaan sosial masyarakat, mengoptimalkan peran agen-agen sosial seperti organisasi kemasyarakatan dan kelembagaan lokal dan menanamkan pendidikan seks usia dini pada anakanak.

Kata Kunci: pedophilia; kriminalitas; perlindungan anak; kekerasan seksual

Permalink/DOI: https://doi.org/10.15408/harkat.v14i2.12814 


\section{Pendahuluan}

Kekerasan seksual terhadap anak yang dilakukan para pedophil merupakan fenomena gunung es di Indonesia. Selama ini, dari banyaknya kasus yang ada, hanya sebagian kecil yang terungkap oleh aparat kepolisian dan media. Hal ini dikarenakan korban kekerasan seksual merupakan anak-anak yang secara psikologis masih polos dan di bawah ancaman pelaku mereka merasa ketakutan untuk menceritakan kekerasan seksual yang dialami sekalipun kepada keluarganya sendiri.

Berdasarkan catatan Komnas Perlindungan Anak pada periode Januari-April 2014, terdapat 342 kasus kekerasan seksual anak. Data yang dihimpun oleh Polri tercatat ada 697 kasus kekerasan seksual yang terjadi di separuh tahun 2014. Dari jumlah itu, sudah 726 orang yang ditangkap dengan jumlah korban 849 orang. Sedangkan KPAI dari bulan Januari-April 2014 menyebutkan ada 622 laporan kasus kekerasan terhadap anak.

Dalam rentang empat bulan telah didapati ratusan kasus yang dilaporkan, namun pastinya ada banyak kasus yang luput dari mata publik karena tidak dilaporkan ke pihak berwajib. Keengganan untuk melaporkan tindak kekerasan seksual yang terjadi pada anak-anak ini karena dari sisi keluarga seringkali kasus kekerasan seksual yang menimpa anak-anak masih dianggap sebagai aib, apalagi jika korbannya anak perempuan, sehingga kekerasan seksual yang terjadi tidak dilaporkan ke pihak yang berwajib bahkan cenderung ditutup-tutupi.

Pemahaman kekerasan seksual sebagai suatu aib di masyarakat ini tentu saja menyulitkan kerja pihak-pihak terkait dalam menangani kasus kekerasan terhadap anak. Tidak dilaporkannya kasus kekerasan seksual tersebut justru menimbulkan ketidakperdulian di masyarakat bahwa ada bahaya kekerasan seksual yang mengancam anak-anak mereka. Akibatnya kontrol sosial masyarakat terhadap kekerasan seksual pada anak-anak menjadi lemah dan kejahatan ini berkembang subur di masyarakat.

Kasus pedophilia di Taman Kanak-Kanak Jakarta International School (JIS) pada tahun 2014 seharusnya membuka kesadaran kita bahwa kekerasan seksual mengancam anak-anak di negeri ini. Menurut catatan Tempo.co edisi 25 April 2014, ada beberapa kasus pedophilia yang terjadi sebelumnya di Indonesia antara lain Tjandra Adi Gunawan yang menyebar 10 ribu foto porno anak-anak di bawah umur pada Tahun 2014, Mario Manara seorang warga negara Italia Tahun 2001, Siswanto (Robot Gedek) pada tahun 1996 dan Baekuni (Babe) tahun 2010. Sementara itu, kasus terbaru kita digegerkan dengan adanya akun facebook komunitas pedophilia yang bernama Loly Candy's. Berbagai kasus ini tentunya membuat keresahan di masyarakat terutama para orang tua.

Berbagai contoh kasus yang telah terjadi di Indonesia tersebut seharusnya menjadi evaluasi bagi kita bersama khususnya pemerintah dalam membuat suatu kebijakan perlindungan terhadap anak. Akan tetapi, yang terjadi hingga saat ini penegakan hukum terhadap para pelaku pedophilia dirasa masih belum sebanding dengan beban psikologis yang harus diderita oleh anakanak sepanjang hidupnya.

Kasus pedophilia yang terjadi tidak hanya menjadikan anak laki-laki menjadi korban, tetapi juga terjadi pada anak perempuan yang berujung pada perkosaan dan pembunuhan sadis untuk meninggalkan jejak si pelaku. Contohnya yang terjadi pada seorang siswi berinisial PNF. Dalam harian Republika.co.id disebutkan PNF yang berusia 9 tahun ditemukan meninggal di dalam kardus di kawasan kalideres. Anak tersebut merupakan korban pencabulan. Hingga 9 Oktober 2015, kepolisian telah menetapkan A yang merupakan tetangga korban sebagai pelaku. 
Namun karena belum cukup bukti maka belum dapat dihukum.

Penelitian yang pernah dilakukan oleh ABC (1983a) mengemukakan bahwa selama ini mitos yang berkembang umumnya pelaku pelecehan seksual merupakan orang asing yang sebagian besar tidak ditangkap dan anak akan segera melupakan trauma karena telah dianiaya. Apabila ditangkap dan jika diserahkan akan diperlakukan dengan lunak. Kurang dari 10 persen pelaku penganiaayaan anak dikirim ke penjara ketika terbukti bersalah. Sedangkan sisanya cenderung dibebaskan oleh para psikiater selama mereka tidak seperti “anjing gila” karena pelaku diasumsikan sebagai penyandang gangguan mental walaupun anak yang dianiaya mengalami luka psikologis yang berkepanjangan (Hagan, 2013).

Pandangan yang mengasumsikan pedophiliac (pelaku pedophilia) sebagai penyandang gangguan mental ini tentu saja tidak menguntungkan dari sisi anak-anak sebagai korban pelecehan seksual. Dengan asumsi ini, para pelaku pedophilia bisa meminta keringanan hukuman atau bebas. Bisa dibayangkan ketika para pedophiliac ini tidak dipandang sebagai tindak kriminalitas, maka yang terjadi bukan hanya pengulangan tindakan tetapi juga hak-hak anak di masyarakat menjadi terancam.

Sebagaimana latar belakang yang sudah dipaparkan, artikel ini bermaksud untuk menjelaskan berbagai kasus pedophilia dari aspek pelaku, kriminalitas dan perlindungan anak. Penting bagi kita bersama untuk memahami pedophilia sebagai suatu penyimpangan atau patologi sosial karena selain melanggar normanorma di masyarakat, perbuatan kekerasan seksual yang dilakukan juga mengancam masa depan anak-anak sebagai generasi penerus.

\section{Profil dan Modus Pelaku Pedofilia}

Konsep pedhophilia sampai saat ini masih menjadi suatu perdebatan di kalangan ahli psikologi klinis dan hukum. Menurut para psikologi ahli klinis seperti Cohen dan Galynker (2002), pelaku pedhophilia merupakan penderita gangguan mental, sementara Kleinhans (2002), memandang bahwa pedophilia merupakan kasus hukum (Harrison, et.al., 2010).

Pedophilia umumnya merujuk pada minat seksual laki-laki terhadap anak-anak. Akan tetapi istilah ini digunakan secara agak terbatas oleh para ahli kejiwaan untuk menunjukkan minat seksual pada anak-anak, karena pedofilia lebih merujuk pada praremaja. Sementara mereka yang mengkhususkan diri dalam perilaku seksual untuk menunjukkan minat seksual pada anakanak dibawah umur biasanya disebut sebagai hebefilia. Dalam hal ini "anak" merupakan dalam batas usia hingga 11 atau 12 tahun (Blanchard, et.,al. 2009). Meskipun ada perbedaan dalam konsep hebefilia dan pedofilia, namun di masyarakat istilah pedofilia lebih dikenal dalam hal ini merujuk pada minat seksual laki-laki terhadap anak-anak dalam hal ini mendasarkan pada definisi UNICEF bahwa "anak" merupakan anak dibawah usia 18 tahun.

Defini klinis yang dikemukakan oleh Cohen dan Galynker (2002) ini memainkan peran penting dalam diagnosis, pengobatan dan reintegrasi pedophiliac. Meskipun pendapat ini memegang peranan penting, akan tetapi banyak pertanyaan yang timbul mengingat para pelaku pedophilia ini memiliki peranan diberbagai bidang dan profesi. Artinya pedhophilia ini tidak hanya menyangkut gangguan kejiwaan tetapi pedhophilia merupakan orientasi seks yang menyimpang di masyarakat.

Pedophiliac (pelaku pedophilia) adalah mereka yang memiliki hubungan seksual dengan anak. Penyimpangan seksual ini merupakan perbuatan yang paling biadab dan dihukum 
dengan hukuman berat. Sebagaimana yang dilakukan oleh kelompok SLAM-Society for Law Againts Molesters melobi hukuman yang keras terhadap pelaku dan pelaku yang mengulangi perbuatannya untuk dihukum penjara minimal 4-8 tahun (Hagan, 2013).

Pendapat ini didasarkan pada kasus-kasus yang terjadi selama ini dimana pedophiliac tidak hanya dilakukan oleh orang dari kelas bawah dengan pendidikan rendah sebagaimana kasus pelecehan seksual umumnya, akan tetapi beberapa kasus di Indonesia menunjukkan bahwa pedophiliac memiliki latar belakang strata sosial yang cukup variatif.

Studi yang dilakukan oleh Karnaji (2017) menyebutkan bahwa status sosial dan profesi pelaku kekerasan seksual terhadap anak selalu memiliki posisi superior terhadap anak dan memegang kekuasaan seperti guru, orang tua, atau orang-orang dari segi usia lebih dewasa. Demikian dengan studi yang pernah dilakukan oleh Cossins dan Malory (2016), mengungkap bahwa selama ini pelaku kekerasan seksual lebih banyak dilakukan oleh laki-laki, sementara korban lebih banyak perempuan. Praktek seksual laki-laki dengan anak-anak merupakan reproduksi normatif dari seksualitas yang maskulin. Artinya mereka mengetahui bahwa berhubungan seksual dengan anak laki-laki merupakan praktek sesksual untuk membuktikan maskulinitas yang tidak dapat mereka lakukan terhadap teman-teman sebayanya.

Hal ini dijelaskan oleh Groth, Burgess, dan Gary (1978, dalam Hagan, 2013) dengan mengklasifikasikan pedophilia menjadi dua tipe: pertama, fixated abuser, yaitu dari awal memiliki fokus pada anak sebagai objek seksual. Kedua, regressed abuser, yaitu orang yang awalnya memiliki kehidupan seksual yang normal, tetapi kemudian mundur memiliki ketertarikan seksual pada anak. Contohnya seorang ayah yang awalnya normal kemudian tiba-tiba mengembangkan ketertarikan seksual pada anak.

Pada pedophiliac fixated abuser ini bisa dilatar belakangi dari reproduksi normatif dari seksualitas yang maskulin yaitu sebagai pembuktian maskulinitas. Sementara untuk regressed abuser tidak hanya disebabkan oleh faktor reproduksi normatif dari seksualitas yang maskulin tetapi juga faktor lain seperti pornografi anak dan preferensi seksual seorang pedophiliac.

Sementara dari sisi objek seksual, Robert G Meyer dan Paul Salmon mengkategorikan pedophilia menjadi dua kategori: pertama, pedophilia homoseksual yaitu objek seksualnya merupakan anak laki-laki dibawah umur dan memiliki perasaan tidak mampu secara seksual khususnya pada wanita dewasa. Kedua, pedophilia heteroseksual yaitu objek seksualnya anak perempuan dibawah umur. Kategori yang kedua ini memiliki perhatian khusus terhadap ukuran alat vitalnya (Zainuddin, 2007).

Modus terjadinya tindak kekerasan seksual oleh pedophilia ini berkembang cukup variatif. Kasus yang terjadi di Indonesia sendiri biasanya dilakukan oleh orang yang memiliki interaksi dengan korban. Biasanya mereka memberi iming-iming kepada korban agar mau dibujuk dan setelah menjadi korban, mereka akan diancam agar tidak melaporkan kepada siapapun sehingga tindak kekerasan seksual ini bisa terjadi berulang-ulang terhadap korban dengan pelaku yang sama.

McCaghy (1976a, h.87, dalam Hagan, 2013) mendefinisikan enam tipe pelecehan seksual pada anak yaitu:

- High interction molesters (para pelaku dengan tingkat interaksi yang tinggi), yang telah mengenal anak dari beberapa waktu dan biasanya telah melakukan timangan genital (genital fondling). 
- Incestuous molesters yaitu pelaku yang mengambil keuntungan terhadap seorang anak yang hidup didalam satu rumah tangga.

- Asocial molesters, yang terlibat dalam karier ilegal

- Senile molesters, pelaku pelecehan seksual yang berusia tua dan kurang pendidikan.

- Career molesters, yang memiliki pola pelanggaran hukum yang melibatkan pelecehan seksual anak.

- Spontaneous aggressive molesters, yang jarang melakukan kontak sebelumnya dengan korban mereka dan cenderung melakukan tindakan dengan pemaksaan secara fisik dan tidak terencana.

Menurut McCaghy (1976 dalam Hagan, 2013) mayoritas pola pelecehan seksual yang terjadi kepada anak adalah pelaku dengan interaksi yang tinggi. $\mathrm{Hal}$ senada juga diungkapkan oleh Lanning (2001), walupun tidak tercatat secara statistik, dalam banyak kasus pelecehan seksual anak pelakunya adalah anggota keluarga, guru, tetangga dan orang-orang terdekat lainnya.

Hal ini merupakan sebuah ironi, dimana lembaga keluarga yang seharusnya memiliki fungsi afeksi dan proteksi bagi anak-anak justru menjadi tempat bersarangnya kejahatan kekerasan seksual terhadap anak-anak. Demikian dengan lembaga lainnya yang seharusnya ramah terhadap anak-anak, justru disitulah anak-anak mengalami tindakan kekerasan seksual.

\section{Pedophilia sebagai kriminalitas}

Pedophilia merupakan tindakan kekerasan seksual yang menghasilkan korban yaitu anakanak. Tidak hanya itu, pedophilia telah melanggar norma-norma dan ketertiban sosial,
Maka sudah seyogyanya praktek-praktek pedophilia dikategorikan kedalam patologi sosial. Oleh sebab itu, diperlukan adanya sanksi tegas bagi pelaku tindakan pedophilia. Para pelaku pedophilia yang umumnya orang dalam kategori dewasa ini bisa dikenakan sanksi pidana karena sudah dianggap memiliki kesadaran dan tanggung jawab pidana atas perbuatan pidana yang dilakukan.

Di dalam sudut pandang hukum umumnya orang dewasa dianggap bukan lagi seorang anak-anak. Orang dewasa akan berhenti memiliki ketergantungan sebagai seorang anak yaitu mereka diatas usia 18 tahun. Sehingga meskipun ada orang dewasa usianya masih muda yang melakukan tindakan pelecehan dan kekerasan seksual terhadap anak tetap dianggap melakukan perbuatan kriminal (meskipun dari perspektif klinis mungkin tidak dianggap pedophilic). Karena tujuan hukum adalah untuk mendefinisikan perilaku kriminal di masyarakat yang dianggap tidak bermoral atau tidak pantas, sehingga tindakan hukum lebih penting daripada usia pelaku (Harrison, et.al., 2010).

Di Indonesia sendiri, hukum tentang perlindungan anak sebenarnya sudah ada yaitu UU No.35 Tahun 2014 yang merupakan perubahan dari UU No.23 Tahun 2002 tentang perlindungan anak. Akan tetapi didalam undang-undang tersebut hanya menyangkut kekerasan terhadap anak secara umum dan belum mengarah kepada kekerasan seksual yang sejatinya membawa dampak lebih berat dan menuntut hukuman lebih berat untuk pelaku agar benar-benar menimbulkan efek jera.

Bahkan di Indonesia sendiri, hukuman bagi pedophiliac masih menjadi perdebatan. Dalam beberapa wacana dan merespon tuntutan masyarakat bahwa pelaku kekerasan seksual terhadap anak mendapatkan hukuman yang setimpal yaitu hukuman mati dan disisi lain berpendapat hukuman kebiri sudah cukup pantas. 
Kejahatan pedophilia merupakan kejahatan terhadap kesusilaan dimana pengertian kesusilaan tidak diartikan secara sempit tetapi terkait norma-norma dan cara bertingkah laku di masyarakat termasuk kejahatan seks. Tindakan ini masuk kedalam delik susila dalam rumusan hukum pidana (Kusuma, 1993).

Kendati demikian, tindakan kekerasan seksual yang dilakukan oleh pedophiliac ini merupakan perilaku seks menyimpang yang menimbulkan kecanduan, maka dalam penanganannya juga harus diorientasikan kepada perlindungan anak itu sendiri melalui pencegahan dan rehabilitasi.

\section{Dampak Pedophilia dan Penanganan}

Perdebatan konsep pedophilia dalam perspektif psikologi klinis dan pidana sudah seyogyanya tidak menjadikan kita terjebak pada sekedar pendefinisian saja. Lebih jauh dari itu, kita harus melihat konsekuensi yang diakibatkan dari adanya tindak kekerasan seksual yang dilakukan oleh phedophiliac terhadap anak.

Dampak pelecehan dan kekerasan seksual terhadap anak telah menjadikan anak mengalami luka psikologis yang berkepanjangan bahkan hingga pada saat anak tersebut dewasa. Anakanak korban pelecehan dan kekerasan seksual secara umum akan rusak masa depannya. Geiser (1979), menyebutkan korban kekerasan seksual anak-anak cenderung akan menderita trauma akut. Masa depannya akan hancur bahkan bisa jadi bunuh diri menjadi pilihan ketika mereka tidak kuat menanggung beban.

Berbeda dengan korban pelecehan dan kekerasan seksual anak perempuan, korban anak laki-laki tidak hanya mengalami trauma psikologi yang berkepanjangan, lebih dari itu mereka berpotensi mengalami disorientasi seksual yang menyimpang karena informasi tentang seksualitas dan maskulinitas yang diterimanya salah. Anak laki-laki yang menjadi korban akan mentransformasikan konsep maskulinitas sebagaimana yang digambarkan oleh para pelaku pelecehan dan kekerasan seksual yaitu berupa hubungan yang mendominasi dan disertai kekerasan.

Studi yang dilakukan Cossins dan Malory (2016), menemukan bahwa anak laki-laki yang menjadi korban pelecehan seksual bisa menjadi pelaku pelecehan seksual dimasa mendatang. Anak-anak korban pelecehan sosial ini belajar untuk mengasosiasikan dengan maskulinitas pelaku pelecehan seksual. Keterlibatan mereka pada praktek seksual dominasi dan kontrol dalam hierarki maskulin menjadikan mereka memilih untuk menyalahgunakan seksual pada kelompok rentan lainnya yang tidak bisa mereka lakukan pada kelompok sebayanya.

Hal senada juga diungkapkan oleh Suyanto (2014), bahwa perkembangan anak lakilaki yang menjadi korban kekerasan seksual akan terganggu. Bukan tidak mungkin mereka akan mengalami pertumbuhan jiwa yang kontradiktif, traumatik dan bahkan sebagian tidak bisa lepas dari penderitaan. Mereka kemudian tumbuh dengan gaya hidup dan persepsi yang keliru tentang seks. Seperti di Thailand, katanya anak laki-laki yang menjadi korban kekerasan seksual jika tidak terbunuh maka kemungkinan saat besar akan terjerumus menjadi gigolo profesional.

Bisa dibayangkan ketika anak sebagai generasi penerus harus mengalami tindakan pelecehan dan kekerasan seksual yang mengancam masa depan mereka. Upaya pendekatan hukum dan pendekatan secara psikologis saja tidaklah cukup membendung bahaya perdator seksual yang setiap saat siap memangsa anak-anak.

Dalam upaya ini diperlukan adanya kerjasama dari berbagai pihak dengan cara mencegah pelecehan dan kekerasan seksual tersebut terjadi, karena berbagai instrumen hukum yang ada saat ini dirasa belum cukup 
efektif dalam melindungi anak-anak dari ancaman kekerasan seksual.

Upaya yang harus dilakukan adalah: pertama, menumbuhkan kepekaan sosial di masyarakat (Suyanto, 2014). Tujuannya adalah untuk meningkatkan kepedulian dan kontrol sosial. Secara teoritik masyarakat yang guyup (tidak individualis) akan memiliki kepedulian dan kontrol sosial yang kuat. Di dalam kondisi masyarakat yang seperti ini berbagai tindak kriminalitas seperti pelecehan dan kekerasan seksual akan sulit berkembang atau sulit dilakukan oleh para pelakunya.

Kedua, upaya yang harus dilakukan adalah meningkatkan peran agen-agen sosial yaitu organisasi kemasyarakatan dan kelembagaan lokal seperti kelompok PKK, keluarga, sekolah, Kelompok Pengajian, dan lain sebagainya sebagai sarana sosialisasi dan kampanye anti pelecehan dan kekerasan seksual pada anak di masyarakat (Kelabur, 2017). Dengan adanya sosialisasi dan kampanye tersebut diharapkan tumbuh kesadaran dan kepedulian terhadap adanya ancaman kekerasan seksual pada anakanak di masyarakat.

Ketiga, mengoptimalkan peran keluarga dan sekolah dalam memberikan pendidikan seks usia dini (Wardhana, 2017). Sebagaimana kita ketahui bersama bahwa hingga saat ini pembicaraan terkait dengan seks masih dianggap hal yang tabu di masyarakat. Seks masih dianggap sebagai wacana dalam arena domestik sehingga hanya diketahui oleh para orang tua. Sementara di era global saat ini, gempuran informasi dari luar termasuk situs-situs pornografi tidak dapat dibendung lagi. Sudah sewajarnya jika lembaga keluarga dan sekolah mulai menjadi referensi bagi anak-anak untuk mengenal seks agar tidak terkontaminasi oleh informasi yang diberikan oleh situs-situs porno di internet tanpa adanya kontrol.

Yang perlu dipahami di sini pendidikan seks bukan dalam artian meakukan tindakan seksual tetapi lebih kepada memberikan pengenalan dan pembekalan terkait kondisi seksualitas, bagian-bagian yang boleh dan tidak boleh disentuh serta perbuatan apa saja yang dikategorikan kedalam tindakan pelecehan maupun kekerasan seksual. Ini bertujuan untuk memberikan bekal kepada anak-anak agar mengenali kondisi seksualitas mereka, sehingga mereka bisa mengenali tindakan pelecehan maupun kekerasan seksual.

\section{Penutup}

Pedophilia merupakan kriminalitas berat karena melanggar hak-hak anak dan mengancam masa depan anak yang menjadi korban. Pedophilia yang terjadi di Indonesia dalam berbagai kasus pelakunya memiliki latar belakang status sosial yang bervariasi. Dilihat dari latar belakang status sosialnya tersebut, pedophilic di Indonesia tergolong kedalam regressed abuser dan fixated abuser dengan modus atau pola kejadian pedophilic yang berhasil melakukan tindakan pelecehan maupun kekerasan seksual merupakan pelaku dengan interaksi tinggi dengan korban dan merupakan orang yang memiliki posisi superior atas korban.

Anak-anak yang menjadi korban pedophilia ini mengalami trauma berkepanjangan, potensi menjadi pelaku di masa depan hingga kematian. Oleh karena itu, dibutuhkan kerjasama dari berbagai pihak dalam upaya pencegahan terjadinya korban pelecehan dan kekerasan seksual melalui peningkatan kepekaan sosial, mengoptimalkan peran organiasi kemasyarakatan dan kelembagaan lokal serta menanamkan pendidikan seks usia dini. Langkah-langkah konkrit ini perlu dilakukan karena dalam penanganan kasus pedophilia ini tidak cukup hanya dengan mengandalkan upaya hukum. 


\section{Daftar Pustaka}

Blanchard, R. et.al. (2009). Absolute Versus Relative Ascertainment of Pedophilia in Men. Sexual Abuse: A Journal of Research and Treatment, 21 (4) 431-441.

Cossins, A., \& Malory P. (2016). MAsculinity and Sexual Abuse: Explaining the Transition from Victim to Offender. Men and Masculinities , 1-26.

Geiser, RL. (1979). Hidden Victims: The Sexual Abuse of Children. Boston: Beacon Press

Hagan, F. E. (2013). Pengantar Kriminologi: Teori, Metode, dan Perilaku Kriminal. Jakarta: Kencana Prenada Media Group.

Harrison, K. et.al (2010). Multi-Disciplinary Definitions and Understandings of 'Paedophilia'. Social and Legal Studies , 19 (4) 481-496.

http://www.kpai.go.id/berita/indonesia-daruratkejahatan-seksual-anak/ diakses pada 20 Maret 2017.

https://nasional.tempo.co/read/news/2014/04/2 5/063573121/8-kasus-pedofilia-yangbikin-geger-indonesia/2 diakses pada 20 Maret 2017.

Karnaji. (2017). Perkosaan Anak Perempuan: Pelaku dan Pola Kejadian. Masyarakat, Kebudayaan dan Politik, 30 (1) 76-83.

Kelabur, Silvester S. (2017). dalam http://www.republika.co.id/berita/koran/fo kus-publik/15/10/16/nwazl28-daruratpedofilia-belum-berakhir pada 20 Maret 2017.
Kusuma, M. W. (1993). Perumusan Tindak Pidana Kesusilaan (Perzinaan dan Pemerkosaan) dalam Rancangan KUHP Baru di Tinjau dari Aspek Kebijakan Kriminal dan Aspek Sosial Budaya. Makalah disampaikan pada seminar sehari tentang Tinjauan Terhadap Rancangan Rancangan KUHP Baru khususnya Tindak Pidana Kesusilaan, Fak. Hukum Universitas Katolik Soegijapranata, Semarang.

Meinck, F., et.al. (2015). Risk and Protective Factors for Physical and Sexual Abuse of Children and Adolescents in Africa: A Review and Implications for Practice. Trauma Violence and Abuse, 16 (1) 81107.

Suyanto, B. (2014). Diakses dalam https://www.tempo.co/read/kolom/2014/0 5/09/1335/ darurat-perlindungan-anak pada 20 Maret 2017

Suyanto, B. (2014). Mewaspadai Monster Pedofilia. Jawa Pos Edisi 19 April 2014.

Wardhana, F. (2017). Diakses dalam http://www.republika.co.id/berita/koran/fo kus-publik/15/10/16/nwazl28-daruratpedofilia-belum-berakhir pada 20 Maret 2017.

Zainuddin, M. (2007). Kebijakan Hukum Pidana Dalam Rangka Penanggulangan Kejahatan Pedofilia. Semarang: Universitas Diponegoro. 